\title{
Oyster Mushroom Spores Ghost Preparation for Medicinal, Biotechnological and Forensic Applications
}

\author{
Ahmed Haddad ${ }^{1}$, Mona M Sharaf ${ }^{2}$, Ahmed M A Kenawy ${ }^{3}$ and Amro Abd Al Fattah Amara*2 \\ ${ }^{1}$ Environmental Biotechnology Department, Genetic Engineering and Biotechnology Research Institute, SRTA-City Alexandria, Egypt \\ ${ }^{2}$ Protein Research Department, Genetic Engineering and Biotechnology Research Institute, SRTA-City Alexandria, Egypt \\ ${ }^{3}$ Nucleic Acids Research Department, Genetic Engineering and Biotechnology Research Institute, SRTA-City, Alexandria, Egypt
}

*Corresponding author: Amro Abd Al Fattah Amara, head of Protein Research Department, Genetic Engineering, and Biotechnology Research Institute, City of Scientific Research and Technological Applications, Universities and Research Center District, New Borg El-Arab, P.O. Box: 21934 Alexandria, Egypt

\section{ARTICLE INFO}

Received: 幽 December 11, 2019

Published: 慧December 19, 2019

Citation: Ahmed Haddad, Mona M Sharaf, Ahmed M A Kenawy, Amro Abd Al Fattah Amara. Oyster Mushroom Spores Ghost Preparation for Medicinal, Biotechnological and Forensic Applications. Biomed J Sci \& Tech Res 24(1)-2019. BJSTR. MS.ID.003994.

Abbreviations: SLP: Sponge Like Protocol; MIC: Minimum Inhibition Concentration; MGC: Minimum Growth Concentration; SLRP: Sponge Like Reduced Protocol

\section{ABSTRACT}

Recently, a simple protocol, named Sponge Like Protocol (SLP) was introduced for the preparation of bacterial ghost cells. This protocol is based on determination of both the minimum inhibition concentration (MIC) and the minimum growth concentration (MGC) of some chemical compounds, which can induce pore(s) formation in the target microbial cell membrane/wall. Fine tuning of the effective concentrations of these chemical compounds enables cell evacuation while maintaining its correct 3D structure. The intact surface antigens are still able to activate the immune system as proven by the previous studies. The current study is a further step to evacuate another cell type, the spores of oyster mushroom, for the first time. The serial dilution method was controlled by direct plate count method to determine the correct concentrations of both MIC and MGC. Both of the DNA and proteins, which were released from the evacuated spores, were determined spectrophotometrically at 260 and $280 \mathrm{~nm}$, respectively. The evacuated spores' quality was determined using both light and electron microscopes. The results showed a typical ghost-spore particle structure that can be used in medicinal, environmental, biotechnological, and forensic applications. We recommend the application of the current protocol for preparing various ghost-spore particles from different fungal origins. This method could have a potential use in reducing fungal spore pollution.

Keywords: Oyster mushroom; Spore; Spore Ghost; Sponge Like Protocol

\section{Introduction}

Different types of edible mushrooms are produced worldwide using different cultivation systems. In most cases, the production process is performed in closed climatized chambers. On the other hand, half-open sheds are also used. In the closed growing chambers, mushrooms produce and accumulate a massive number of spores causing severe problems including the developing of respiratory complaints 'mushroom workers' lung' [1-3]. Contact with the mushroom spores is the main claimed factor. Mushroom spores may cause irregular breathing, coughing, shivering, fever and myalgia, in addition to lung volume decrease and increase in the number of white blood cells. Pleurotus ostreatus, pearl or tree oyster mushroom is an important edible mushroom. It has been cultivated in Germany for the first time during the World War I to be used as food [4-9]. Oyster mushroom is also used for myco-remediation. It can be cultivated on straw and other natural or synthetic media [10-12]. It is one of the whiterot woods-decay fungi. It is a saprotrophic fungus that acts as a primary decomposer of wood, especially deciduous trees [13-18]. P. ostreatus has different names. Oyster mushrooms are mainly cultivated in large clear polyethylene bags with buns of hay layered in the bags, and spawn sown between the layers. It is also used in soups and stews in a similar fashion to meat [19-21]. Oyster 
mushrooms contain small amounts of arabitol, a sugar alcohol, which may cause gastrointestinal upset in some people $[22,23]$. It causes hypersensitivity for individuals in direct contact with its spores particularly for long time $[3,24,25]$.

Evacuating microbes from their cytoplasmic content is a natural phenomenon [26]. Amara et al. (2013) [27] and others reported that pores could be introduced to the microbial cell walls and/or membranes as a result of different mechanisms [26,28-31], such as evacuating the gram-negative bacteria via bacteriophage infection [26]. Bacteriophage $E$ lysis gene is used for evacuating bacterial cells and turning them into ghost cells via controlling their expression using heat sensitive promoter [26,28,31-34]. Recently, the Sponge Like Protocol was introduced [27,35,36]. Its main concept is using active chemical compounds that can induce pores in the microbial cell membrane/wall and degrade its DNA at concentrations that do not change the surface antigens or the 3D structure [35]. This enables the evacuation of each of gramnegative, gram-positive spore forming bacteria and eukaryotes such as the yeast, as well as viruses such as Newcastle virus [26,3548]. Recently, both Aspergillus flavus and Aspergillus niger, and their spores were evacuated and turned into ghost-spores [49,50].

SDS was proved to have the ability to perturb and destabilize cell wall/plasma membranes of both yeasts and fungi at very low concentrations [51]. SDS is also able to degrade the cell wall. $\mathrm{H}_{2} \mathrm{O}_{2}$ has oxidizing activity and able to degrade the genetic material instead of nucleases [38]. $\mathrm{NaOH}$ is also known for its damaging effect on microbial cell walls and a degrading capability for both DNA and RNA. It can deactivate microbial cells and can be used alone as antimicrobial agent as proved from the previous studies of microbial ghost cells preparations. $\mathrm{NaHCO}_{3}$ has a recognizable effect as salt and alkali as proved by Amara and Steinbüchel (2013). It can deactivate various microbes or slow the growth of others in particular concentrations and for that it could be used in Spirulina platansis selective media. In this way, it has substituted $\mathrm{CaCO}_{3}$ in preparing ghost microbes other than Gram-negative bacteria. It might be useful to highlight that Amara and Steinbüchel have selected $\mathrm{NaHCO}_{3}$ based on a natural phenomenon that the Lake becomes dominant with $S$. platensis during the summer due to the evaporation of its water content and the increase in its salt content, where carbonate is the major constituent. Both of $\mathrm{pH}$ and salinity were responsible for eradicating various algal species and keeping the lake clean with an exception that $S$. platensis could grow as a dominant cyanobacteria turning the colour of the lake to the cyanogreen colour [52]. In this study, for the first time, the spores of the oyster mushroom were evacuated from their content and turned into ghost particles using the concept of Sponge Like Protocol.

\section{Materials and Methods}

\section{Isolation of the Oyster Mushroom}

Mushroom fruiting bodies from Borg El-Arab region, Alexandria, Egypt, were collected during winter season and stored at $4{ }^{\circ} \mathrm{C}$. Under sterile conditions, small tissues of the wild fruiting bodies were transferred to the PDA plates. The mycelia tissue was placed in the center of the plate, so that growth can radiate away from it. The plates were incubated at $28{ }^{\circ} \mathrm{C}$ for 7 days. After full colonization, the plates were stored at $4{ }^{\circ} \mathrm{C}$.

\section{Morphological Identification}

The fungal isolate was identified morphologically after growing on rice straw by observing its macroscopic features including: $\mathrm{Cab}$ and stem morphology, spore-print and microscopic shape of spores.

\section{Oyster Mushroom Spawn Preparation}

Spawn of the mushroom was prepared in $250 \mathrm{ml}$ bottles using sorghum grains. The grains were washed with water thoroughly to clean the dirt, then boiled in water until being semi soft, after cooling to room temperature, the excess water was drained off and the grains were mixed with $5 \%(\mathrm{w} / \mathrm{w}) \mathrm{CaSO}_{4}$. The bottles were filled to $3 / 4$ with sorghum grains and sterilized by autoclaving at $121^{\circ} \mathrm{C}$ and 1.5 bar for 15 minutes. The sorghum grains were inoculated with actively growing mycelium of oyster mushroom from PDA plates and incubated at $28^{\circ} \mathrm{C}$. Mycelial growth were allowed for 12 to 15 days until the mycelium fully covered the grains.

\section{Oyster Mushroom Cultivation}

Pleurotus sp. was cultivated using the perforated polythene bag method with minor modifications $[53,54]$. Dried rice straw was chopped into 5 to $7 \mathrm{~cm}$ length and soaked in water for 4 hours in the presence of $5 \%(\mathrm{w} / \mathrm{w})$ gypsum, and excess water was drained off. The substrate was sterilized by autoclaving at $121^{\circ} \mathrm{C}$ and $1.5 \mathrm{bar}$ for $20 \mathrm{~min}$. About half kilogram of the substrate was placed in $40 \mathrm{~cm}$ width X $60 \mathrm{~cm}$ length polyethylene bags and spawned with $10 \%$ of the mushroom mycelia grown on sorghum grains. Spawning was done in 3 layers each above $5 \mathrm{~cm}$ layer of the rice straw substrate. The bags were subsequently placed into spawn running room at $25^{\circ} \mathrm{C} \pm 2$ under dark conditions. After the completion of spawn running, polythene bags were placed into the fructification room at $23^{\circ} \mathrm{C} \pm 2$ and $75-85 \%$ relative humidity. The bags were cut open on the sides without disturbing the beds and sprayed twice a day with water for maintaining a high moisture level. The bags were exposed to light for 5-7 hours/day and left until the appearance of the mushroom pinheads. The fruiting bodies appear two weeks after bags perforation for 3-successive flushes. Mushroom was matured within 2-3 days after pinhead's initiation. Mushroom was harvested by twisting the fruiting body to displace it from the base.

\section{Collection of Oyster Mushroom Spores}

The stems of the fresh oyster mushroom fruiting bodies were cut at the base of the fan-shaped cap. Then, the oyster mushroom cap was placed on a clean white paper with the underside down on the paper. A glass cup was placed over the mushroom cap and kept in a cool and dry place for 24 to $48 \mathrm{hrs}$. The glass cup and the mushroom cap were removed to find a spore print of the mushroom cap where the spores collected on the paper. Finally, the spores were collected in an Eppendorf tube by scrapping off the paper using sterile scalpel. 


\section{Determination of the MIC and MGC Concentrations for $\mathrm{NaOH}, \mathrm{SDS}, \mathrm{NaHCO}_{3}$ and $\mathrm{H}_{2} \mathrm{O}_{2}$ and Spore Viability}

Standard broth microdilution susceptibility assay was used for determining the MIC values for each of $\mathrm{NaOH}, \mathrm{SDS}, \mathrm{NaHCO}_{3}$ and $\mathrm{H}_{2} \mathrm{O}_{2}[35,36]$. Ten Eppendorf tubes, each contain $3 \mathrm{mg}$ of the spores in one $\mathrm{ml}$ of water were used. Different stocks of the used chemical compounds represent: $10 \%$ of $\mathrm{NaOH}$ (non-autoclaved), SDS (autoclaved), $\mathrm{NaHCO}_{3}$ (autoclaved), and $30 \%$ of $\mathrm{H}_{2} \mathrm{O}_{2}$ (commercial grade purchased from a pharmacy). After overnight incubation, direct plat count were performed by spreading $100 \mu \mathrm{l}$ of each spores-treated solution on PDA medium and the plates were incubated at $30{ }^{\circ} \mathrm{C}$ for 5 days. The MIC value for each compound was calculated as well as the concentration that allowed first fungal growth detection (abbreviated as MGC) representing the concentration showing first growth after the MIC.

\section{Determination of DNA / Protein Concentrations}

The concentration of DNA in the supernatant, after each step for each randomization experiment, was determined spectrophotometrically by measuring the absorbance at $260 / 280 \mathrm{~nm}$ using spectrophotometer (Biochrom LTD, Cambridge CB4 OFG, England). An extinction coefficient $260=1$ corresponds to $50 \mu \mathrm{g}$ dsDNA mL ${ }^{-1}$ [54]. The DNA concentration was calculated automatically by the aid of the software of the spectrophotometer [55].

\section{Spore Cells Evaluation Using Light Microscope}

Spore cells generated from different treatments were investigated using light microscopy. The spores were stained on glass slides using crystal violet stain for $1 \mathrm{~min}$, and then examined under light-microscope to check the evacuation process during various steps of the treatments.

\section{Sample Preparation for Electron Microscope Examination}

For further investigation of the quality of the ghost-spores, electron microscope was used to scan the spore particles. A spore smear of each preparation was prepared, and the smear surface was then coated with approximately $15 \mathrm{~nm}$ gold layer (SPI-Module Sputter Coater).

\section{Scanning of the Prepared Ghost-Spores (SGs) Surface}

The gold-coated samples were scanned by analytical scanning electron microscope (Jeal JSM-6360, LA) with secondary element at $10 \mathrm{kv}$ acceleration voltage at room temperature. The digital images were then adjusted and analyzed.

\section{Results and Discussion}

Different groups of fungi are well known for their ability to produce spores as a part of their reproduction process and for protecting their origin. Such spores are usually more resistant to harsh environmental conditions and are able to spread everywhere. They are capable to reach our bodies particularly to our lungs.
Some of them could cause severe illness for us, some cause allergy, while others if entered in small amounts might be safe. However, apparently, the exposure to safe spores for long time might cause different kind of illness [56]. Finding spore-less strains could be a good solution to this problem; however, establishing a protocol for deactivating the spores might be efficient to eliminate any kind of risk, particularly to the workers in mushroom production facilities. The size of some types of mushroom spores are quite bigger than other types of spore former fungi. Mushroom spores cause seasonal allergy for sensitive individuals. Deactivating such spores might be useful, while some types of spore-sensitivity are linked to the activity of the spores during their vegetation. In drug delivery system technology, empty mushrooms' spores could be a good candidate, that could enrich different medicinal and biotechnological applications.

Mushrooms spores are invited candidates in forensic investigation, establishing a protocol for evacuating the mushroom spores using the concept of MIC will enable better realise to their DNA and protein contents. In some cases, the amount of the spores is too small and efficient protocol for isolating their DNA to be amplified by different PCR protocols are in demand. For those previous aspects, this study has been conducted to investigate the possibility of producing mushroom ghost-spores using the concept of the Sponge Like Protocol, which is based mainly on the determining of the MIC and MGC of some chemical compounds. These chemical compounds are able to introduce pores into the cell walls and membranes. Each of Gram positive, Gram-negative, spore forming bacteria, yeast, fungi, and virus were turned into ghost cells using either SLP or the Sponge like Reduced Protocol (SLRP). The MIC for $\mathrm{NaOH}, \mathrm{SDS}$, and $\mathrm{H}_{2} \mathrm{O}_{2}$ was determined. In case of $\mathrm{H}_{2} \mathrm{O}_{2}$, the MIC was $1.11 \mathrm{~mL} / \mathrm{mL}$ from $30 \% \mathrm{H}_{2} \mathrm{O}_{2}$. In case of SDS, MIC was $0.045 \mathrm{mg} /$ mL. Meanwhile, MIC of $\mathrm{NaOH}$ was $0.045 \mathrm{mg} / \mathrm{mL}$, and for $\mathrm{NaHCO}_{3}$ the MIC was $3.7 \mathrm{mg} / \mathrm{mL}$. The MGC of $\mathrm{NaOH}$, SDS, and $\mathrm{H}_{2} \mathrm{O}_{2}$ was determined. In case of $\mathrm{H}_{2} \mathrm{O}_{2}$, the MIC was $0.37 \mathrm{~mL} / \mathrm{mL}$ from $30 \% \mathrm{H}_{2} \mathrm{O}_{2}$. In case of SDS the MIC was $0.015 \mathrm{mg} / \mathrm{mL}$. In case of $\mathrm{NaOH}$ the MIC was $0.015 \mathrm{mg} / \mathrm{mL}$, and for $\mathrm{NaHCO}_{3}$ the $\mathrm{MIC}$ was $1.23 \mathrm{mg} / \mathrm{mL}$.

The unique part in this study is the investigation of the viability of the spores after each treatment during the serial dilution experiments using direct plate cultivation. The serial dilution method was done without the use of nutrients and only water was used. Using nutrients during the serial dilution experiment enable some microbes to develop some sort of defence mechanisms during the treatment as proved in previous studies. For example, the development of exopolysaccharide during $K$. pneumonia treatment [56]. $\mathrm{H}_{2} \mathrm{O}_{2}$ is a potent agent in degrading both of DNA and RNA macro-molecules as proved by El Baky and Amara (2014). As shown in Table 1 different treatments showing successful release of both the DNA and protein. This was confirmed by the images obtained from the electron microscope as images from a to e in Figure 1. The protocol also succeeded to turn virus to ghost empty and inactive virus [38]. However, in order to prove the killing effect of different 
used compounds, direct cultivation on plates contain nutrients was done. This step gives better determination for the MIC and the MGC. Moreover, the usage of one $\mathrm{ml}$ of water and half $\mathrm{ml}$ of the chemical compound has led to narrowing the dilution differences, which give better MIC and MGC. In a previous study, we used $4.5 \mathrm{ml}$ of the medium and $0.5 \mathrm{ml}$ of the chemical compound, which give high dilution within the tubes. Both DNA and Protein percentages were calculated directly after the serial dilution experiment as in Table 1 . The centrifugation, which happened only during collecting the spores from the treated samples to analyse them by either the electron or light microscopes, also help in evacuating the spores from their contents as shown in Figure 1 and Figure 2. This study considered as is an additional step for evacuating different microbes as well as their components such as the spore of mushrooms. Using the main concept of the cell evacuation protocol as described by Amara et al. (2013)[27] by using different chemical compounds after determining their minimum inhibition concentration.

Table 1: DNA concentrations of different spore-treated supernatants.

\begin{tabular}{|c|c|c|c|c|c|c|c|c|}
\hline \multirow{3}{*}{ Sample } & \multicolumn{8}{|c|}{ A260/A280 for Different Ghost Preparation Steps } \\
\hline & \multicolumn{2}{|c|}{$\mathrm{NaHCO}_{3}$} & \multicolumn{2}{|c|}{$\mathrm{H}_{2} \mathrm{O}_{2}$} & \multicolumn{2}{|c|}{ SDS } & \multicolumn{2}{|c|}{$\mathrm{NaOH}$} \\
\hline & A260/A280 & Conc. $\mathrm{Mg} / \mathrm{ml}$ & A260/A280 & Conc. $\mathrm{Mg} / \mathrm{ml}$ & A260/A280 & Conc. $\mathrm{Mg} / \mathrm{ml}$ & A260/A280 & Conc. $\mathrm{Mg} / \mathrm{ml}$ \\
\hline 1 & 1,322 & 80,03 & 2,247 & 80,03 & 1,448 & 84,39 & 1,622 & 70,12 \\
\hline 2 & 1,279 & 61,03 & 1,994 & 61,03 & 1,463 & 60,2 & 1,597 & 80,49 \\
\hline 3 & 1,169 & 44,38 & 1,997 & 44,38 & 1444 & 59,96 & 1,722 & 78,86 \\
\hline 4 & 1,173 & 40,34 & 1,56 & 20,75 & 1,444 & 59,49 & 1,72 & 73,79 \\
\hline 5 & 1,13 & 20,48 & 1,56 & 20,75 & 1,455 & 61,37 & 1,706 & 78,99 \\
\hline 6 & 1,07 & 38,42 & 1,381 & 24,81 & 1,489 & 62,89 & 1,758 & 89,57 \\
\hline 7 & 1,239 & 53,93 & 1,721 & 21,61 & 1,55 & 67,12 & 1,797 & 81,39 \\
\hline 8 & 1,456 & 26,82 & 2,304 & 22,8 & 1,564 & 74,17 & 1,759 & 51,33 \\
\hline 9 & 1,672 & 29,62 & 1,616 & 32,41 & 1484 & 64,23 & 2,146 & 29,68 \\
\hline 10 & 1,527 & 32,18 & 1,527 & 20,68 & 1,546 & 22,64 & 1,506 & 48,33 \\
\hline
\end{tabular}

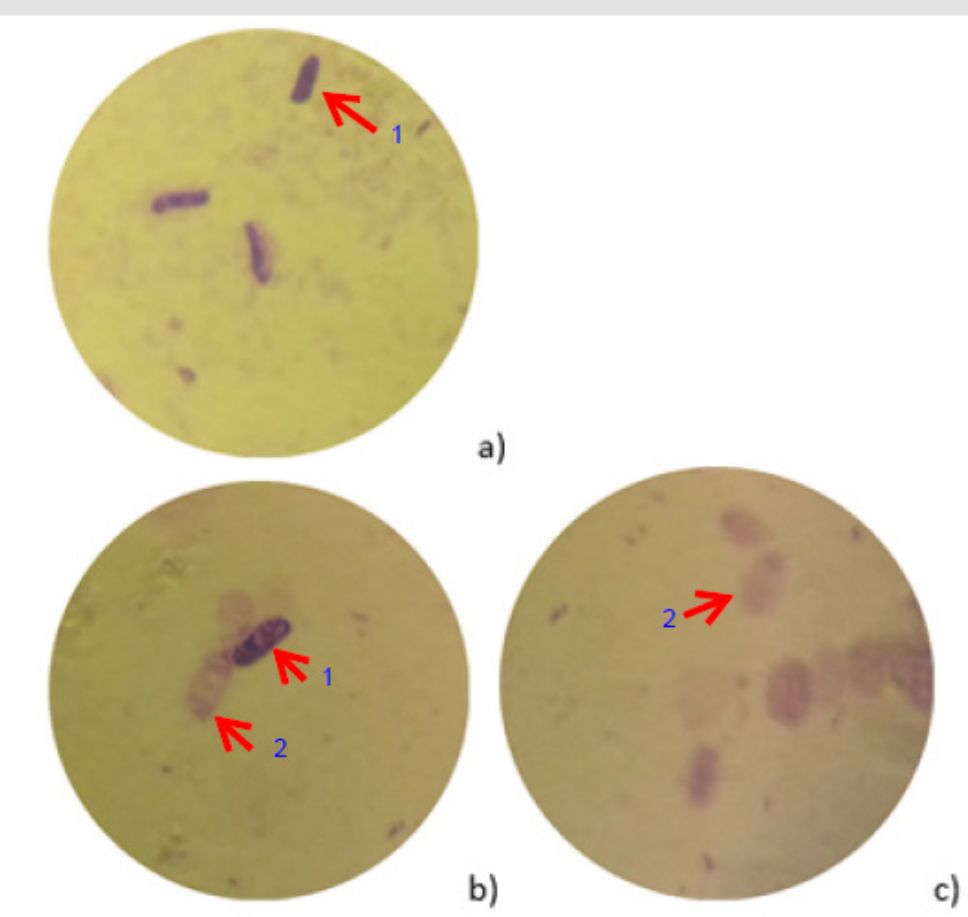

Figure 1: Different levels of the evacuation, spores (stained with crystal violeta)

a) Wild spore without treatment,

b) During the treatment processes (some of the spores still intact)

c) After treatment (all spores are evacuated) (Arrows: 1) non-evacuated spore; 2) evacuated spore). 


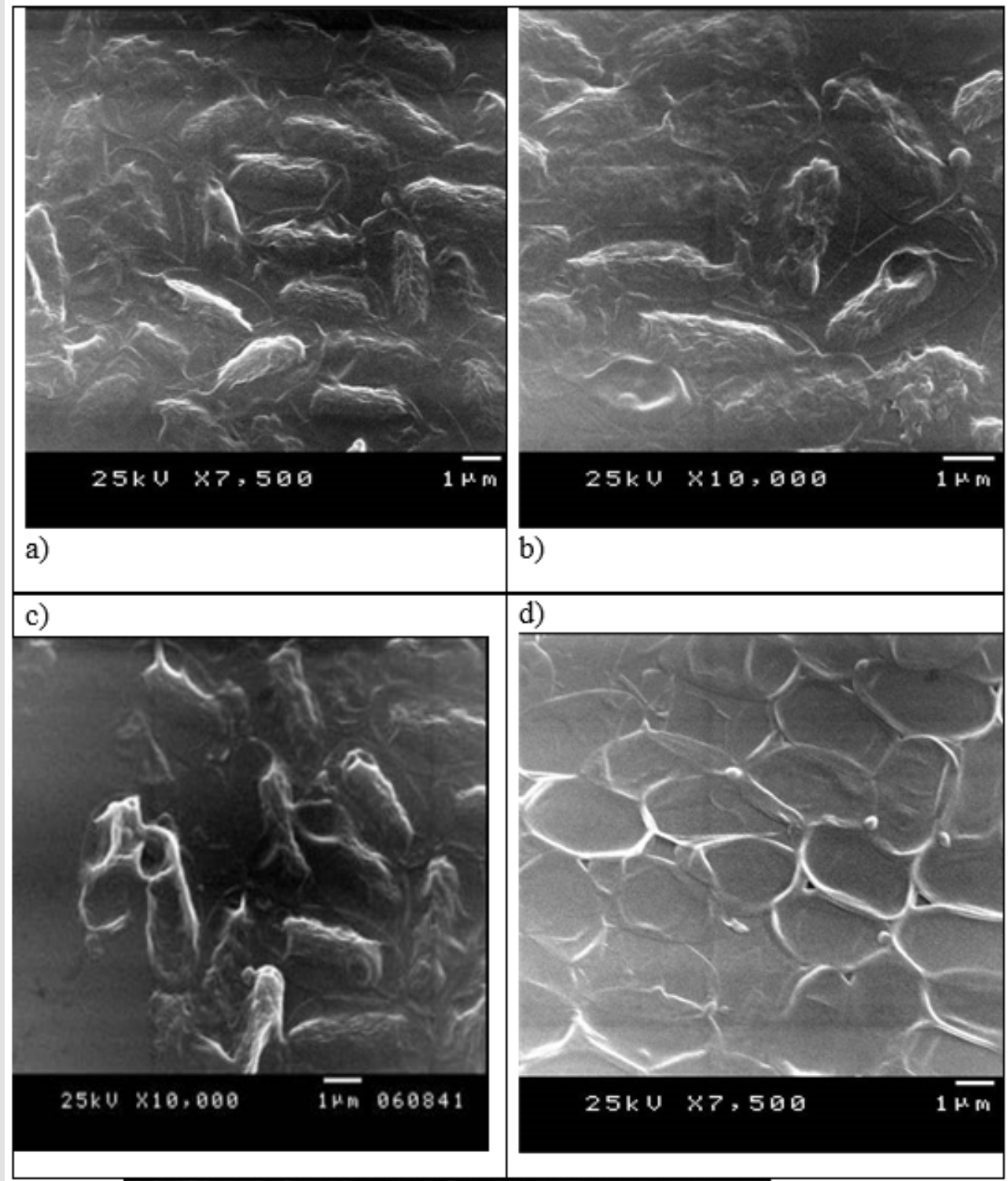

e)

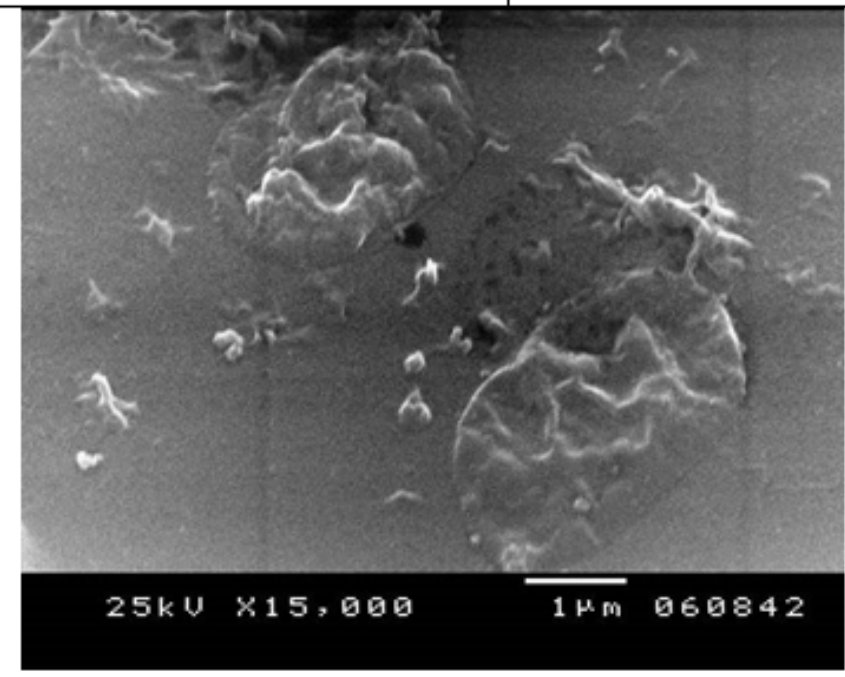

Figure 2: a) Scanning electron microscope of the wild mushroom spore at $7500 \mathrm{X}$; b) and c) treated spores at $10000 \mathrm{X}$; d) the treated spores show clear evacuation of their contents at 7500; e) coat. 


\section{References}

1. Cox A, Folgering HT, van Griensven LZ (1988) Extrinsic allergic alveolitis caused by spores of the oyster mushroom Pleurotus ostreatus. Eur Respir J 1(5): 466-488.

2. Noster U, Hausen BM, Felten G, Schulz (1976) [Mushroom worker's lung caused by inhalation of spores of the edible fungus pleurotus Florida ("oyster mushroom") (author's transl)]. Dtsch Med Wochenschr, 101(34): 1241-1245.

3. Horner WE, Ibanez MD, Liengswangwong V, Salvaggio JE, SLehrer SB (1988) Characterization of allergens from spores of the oyster mushroom, Pleurotus ostreatus. J Allergy Clin Immunol 82(6): 978-986.

4. Bukhalo AS, Parkhomenko LP, Martinenko MM (1975) Growth of mycelium of Pleurotus ostreatus (Fr.) Kummer in pure culture. Mikrobiol Zh 37(2): 181-184.

5. Obodai M, Cleland Okine J, Vowotor KA (2003) Comparative study on the growth and yield of Pleurotus ostreatus mushroom on different lignocellulosic by-products. J Ind Microbiol Biotechnol 30(3): 146-149.

6. Tedesco G, Marchi A, Gerola FM (1983) Immunological study on the wall proteins of different fruiting portions in Pleurotus ostreatus (Jacq. ex Fr.) Kummer and Agaricus bisporus (Lge.) Sing. G Batteriol Virol Immunol 76(7-12): 200-206

7. Aggelis G, Iconomou D, Christou M, Bokas D, Kotzailias S, et al. (2003) Phenolic removal in a model olive oil mill wastewater using Pleurotus ostreatus in bioreactor cultures and biological evaluation of the process. Water Res 37(16): 3897-3904.

8. Alarcon J, Aguila S (2006) Lovastatin production by Pleurotus ostreatus: effects of the C:N ratio. Z Naturforsch C 61(1-2): 95-98.

9. Assi JA, King AJ (2007) Assessment of selected antioxidants in tomato pomace subsequent to treatment with the edible oyster mushroom, Pleurotus ostreatus, under solid-state fermentation. J Agric Food Chem 55(22): 9095-9098.

10. Bhattacharya S, Das A, Prashanthi K, Palaniswamy M, Angayarkanni J Mycoremediation of Benzo[ $\alpha]$ pyrene by Pleurotus ostreatus in the presence of heavy metals and mediators. 3 Biotech 4(2): 205-211.

11. Migliore L, Fiori M, Spadoni A, Galli E (2012) Biodegradation of oxytetracycline by Pleurotus ostreatus mycelium: a mycoremediation technique. J Hazard Mater 215-216: 227-232.

12. Vaseem H, Singh VK, Singh MP (2017) Heavy metal pollution due to coal washery effluent and its decontamination using a macrofungus, Pleurotus ostreatus. Ecotoxicol Environ Saf 145: 42-49.

13. Eichlerova I, Homolka L, Nerud F, Zadrazil F, Baldrian P, et al. (2000) Screening of Pleurotus ostreatus isolates for their ligninolytic properties during cultivation on natural substrates. Biodegradation 11(5): 279287.

14. Rigas F, Dritsa V, Marchant R, Papadopoulou K, Avramides EJ et al. (2005) Biodegradation of lindane by Pleurotus ostreatus via central composite design. Environ Int 31(2): 191-196.

15. Verma P, Madamwar D (2002) Production of ligninolytic enzymes for dye decolorization by cocultivation of white-rot fungi Pleurotus ostreatus and phanerochaete chrysosporium under solid-state fermentation. Appl Biochem Biotechnol 102-103(1-6): 109-118.

16. Wojtas Wasilewska M, Trojanowski J (1975) Studies on the decomposition of lignosulfonates by the fungi Pleurotus ostreatus and Trametes pubescens. Acta Microbiol Pol B 7(2): 77-90.

17. da Luz JM, Paes SA, Bazzolli DM, Totola MR, Demuner AJ, et al. (2014) Abiotic and biotic degradation of oxo-biodegradable plastic bags by Pleurotus ostreatus. PLoS One 9(11).

18. Rosado FR, Germano S, Carbonero ER, Da Costa SM, Iacomini M, et al. (2003) Biomass and exopolysaccharide production in submerged cultures of Pleurotus ostreatoroseus Sing. and Pleurotus ostreatus "florida" (Jack.: Fr.) Kummer. J Basic Microbiol 43(3): 230-237.
19. Alam N, Amin R, Khan A, Ara I, Shim MJ, et al. (2008) Nutritional Analysis of Cultivated Mushrooms in Bangladesh - Pleurotus ostreatus, Pleurotus sajor-caju, Pleurotus florida and Calocybe indica. Mycobiology 36(4): 228-232.

20. Asada Y, Watanabe A, Irie T, Nakayama T, Kuwahara M (1995) Structures of genomic and complementary DNAs coding for Pleurotus ostreatus manganese (II) peroxidase. Biochim Biophys Acta 1251(2): 205-209.

21. Assi JA, King AJ (2008) Manganese amendment and Pleurotus ostreatus treatment to convert tomato pomace for inclusion in poultry feed. Poult Sci 87(9): 1889-1896.

22. Adams S, Che D, Hailong J, Zhao B, Rui H, et al. (2019) Effects of pulverized oyster mushroom (Pleurotus ostreatus) on diarrhea incidence, growth performance, immunity, and microbial composition in piglets. J Sci Food Agric 99(7): 3616-3627.

23. Zhong L, Ma N, Wu Y, Zhao L, Ma G, et al. (2019) Gastrointestinal fate and antioxidation of beta-carotene emulsion prepared by oat protein isolatePleurotus ostreatus beta-glucan conjugate. Carbohydr Polym 221: 10-20.

24. Jesenak M, Hrubisko M, Majtan J, Rennerova Z, Banovcin P (2013) Anti-allergic effect of Pleuran (beta-glucan from Pleurotus ostreatus) in children with recurrent respiratory tract infections. Phytother Res 28(3): 471-474.

25. Paulik S, Svrcek, Mojzisova J, Durove A, Benisek Z, et al. (1996) The immunomodulatory effect of the soluble fungal glucan (Pleurotus ostreatus) on delayed hypersensitivity and phagocytic ability of blood leucocytes in mice. Zentralbl Veterinarmed B 43(3): 129-135.

26. Amara AA (2016) Lysozymes, Proteinase K, Bacteriophage E Lysis Proteins, and some Compounds for Microbial ghosts Preparation: A Review and Food for Thought. SOJ Biochem 2(1): 1-16.

27. Amara AA, Salem Bekhit MM, Alanazi FK (2013) Sponge-like: a new protocol for preparing bacterial ghosts. The Scientific World Journal.

28. Dong H, Han X, Bai H, He L, Liu L, et al. (2012) Mutation of lambdapL/pRcI857 system for production of bacterial ghost in Escherichia coli. Sheng Wu Gong Cheng Xue Bao 28(12): 1423-1430.

29. Laemmli UK (1970) Cleavage of structural proteins during the assembly of the head of bacteriophage T4. Nature 227: 680-685.

30. Makino K, Yokoyama K, Kubota Y, Yutsudo CH, Kimura S, et al. (1999) Complete nucleotide sequence of the prophage VT2-Sakai carrying the verotoxin 2 genes of the enterohemorrhagic Escherichia coli 0157: H7 derived from the Sakai outbreak. Genes \& genetic systems 74(5): 227239.

31. Panthel K, Jechlinger W, Matis A, Rohde M, Szostak M, et al. (2003) Generation of Helicobacter pylori ghosts by PhiX protein E-mediated inactivation and their evaluation as vaccine candidates. Infect Immun 71(1): 109-116.

32. Hensel A, Huter V, Katinger A, Raza P, Strnistschie C, et al. (2000) Intramuscular immunization with genetically inactivated (ghosts) Actinobacillus pleuropneumoniae serotype 9 protects pigs against homologous aerosol challenge and prevents carrier state. Vaccine 18(26): 2945-2955.

33. Weibull C (1956) The nature of the ghosts obtained by lysozyme lysis of Bacillus megaterium. Exp Cell Res 10(1): 214-221.

34. Witte A, Wanner G, Sulzner M, Lubitz W (1992) Dynamics of PhiX174 protein E-mediated lysis of Escherichia coli. Arch Microbiol 157(4): 381388.

35. Amara AA, Salem Bekhit MM, Alanazi FK (2013) Sponge-like: a new protocol for preparing Bacterial Ghosts. TSWJ 23(89): 1013.

36. Amara AA (2015) Saccharomyces cerevisiae Ghosts Using the SpongeLike Re-Reduced Protocol SOJ Biochem p. 1-4.

37. Amara AA, Neama AJ, Hussein A, Hashish EA, Sheweita SA (2014) Evaluation the surface antigen of the Salmonella typhimurium ATCC 14028 ghosts prepared by "SLRP". Scientific World Journal 2014: 840863 . 
38. El Baky NA, Amara AA (2014) Newcastle disease virus (LaSota strain) as a model for virus Ghosts preparation using $\mathrm{H} 2 \mathrm{O} 2$ bio-critical concentration. International Science and Investigation journal 3(5): 3850

39. Vinod N, Oh S, Kim S, Choi CW, Kim SC et al. (2014) chemically induced salmonella enteritidisghosts as anovel vaccine candidate against virulent challenge in arat model. Vaccine 32(26): 3249-3255.

40. Amara AA (2015) Bacterial and Yeast Ghosts: E. coli and Saccharomyces cerevisiae preparation as drug delivery model ISIJ Biochemistry 4(7): 11-22.

41. Amara AA (2015) Kostenlos viral ghosts, bacterial ghosts' microbial ghosts and more. Schuling Verlag - Germany.

42. Vinod N, Oh S, Park HJ, Koo JM, Choi CW, et al. (2015) Generation of a Novel Staphylococcus aureus Ghost Vaccine and Examination of Its Immunogenicity against Virulent Challenge in Rats. Infect Immun 83(7): 2957-2965.

43. Amara AA (2016) The critical activity for the cell all degrading enzymes: Could the use of the lysozyme for microbial ghost's preparation establish emergance oral vaccination protocol? International Science and Invastigation Journal 5(2): 351-369.

44. Amara AA (2016) Vaccine against pathogens: A review and food for thought. SOJ Biochemistry 2(2): 1-20.

45. Hussain ZM, Amra AA (2016) Case-by-case study using antibiotic-EDTA combination to control Pseudomonas aeruginosa. Pak J Pharm. Sci19(3): 236-243.

46. Park HJ, Oh S, Vinod N, Ji S, Noh HB, et al. (2016) Characterization of Chemically Induced Bacterial Ghosts (BGs) Using Sodium HydroxideInduced Vibrio parahaemolyticus Ghosts (VPGs). International Journal of Molecular Sciences 17(11): 1904.

47. Wu X, Ju X, Du L, Yuan J, Wang L, et al. (2017) Production of Bacteria Ghosts from Gram-Positive Pathogen Listeria monocytogenes. Foodborne Pathogens and Disease 14(1): 1-7.

\section{ISSN: 2574-1241}

DOI: 10.26717/BJSTR.2019.24.003994

Amro Abd Al Fattah Amara. Biomed J Sci \& Tech Res

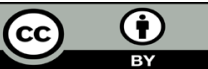

This work is licensed under Creative

Commons Attribution 4.0 License

Submission Link: https://biomedres.us/submit-manuscript.php
48. Menisy MM, Ghazy A, Sheweita S, Amara AA (2017) Klebsiella pneumoniae Ghosts as Vaccine Using Sponge Like Reduced Protocol. Cellular and Molecular Medicine 3(2): 8.

49. Abd El-Baky N, Sharaf MM, Amer E, Kholef HR, Hussain MZ, Amara AA, et al. (2018) Protein and DNA Isolation from Aspergillus Niger as well as Ghost Cells Formation. SOJ Biochemistry 4(1): 1-7.

50. Abd El-Baky N, Sharaf MM, Amer E, Kholef HR, Hussain MZ, RA Abdel Rahman, Amara AA, et al. (2018) The minimum inhibition and growth concentrations for controlling fungal infections as well as for ghost cells preparation: Aspargillus flavus as a model. Biomedical Journal of Scientific and Technical Research 10(2): 1-5.

51. Delley PA, Hall MN (1999) Cell wall stress depolarizes cell growth via hyperactivation of RH01. J Cell Biol 147(1): 163-174.

52. Amara AA, Steinbüchel A (2013) New medium for pharmaceutical grade Arthrospira. Int J Bacteriol 9: 1-9.

53. Nehal M EL Deeb, Hala I EL Adawi, Abeer E Abd EL wahab, Ahmed M Haddad, Hesham A EL Enshasy, et al. (2019) Modulation of NKG2D, KIR2DL and Cytokine Production by Pleurotus ostreatus Glucan Enhances Natural Killer Cell Cytotoxicity Toward Cancer Cells. Frontiers in Cell and Developmental Biology 7.

54. Bano Z and Srivastava H (1962) Studies in the cultivation of Pleurotus sp. on paddy straw. Food Sci 12: 363-368.

55. Sambrook J, Fritsch EF and Maniatis T (1989) Molecular Cloning a Laboratory Manual ( $2^{\text {nd }}$ Edn). Cold Spring Harbor Laboratory, Cold Spring Harbor, NY, USA.

56. Menisy MM, Hussein A, Ghazy A, Sheweita S, Amara AA (2017) Klebsiella pneumoniae ghosts as vaccine using sponge like reduced protocol. Cellular and Molecular Medicine 3(2): 11.

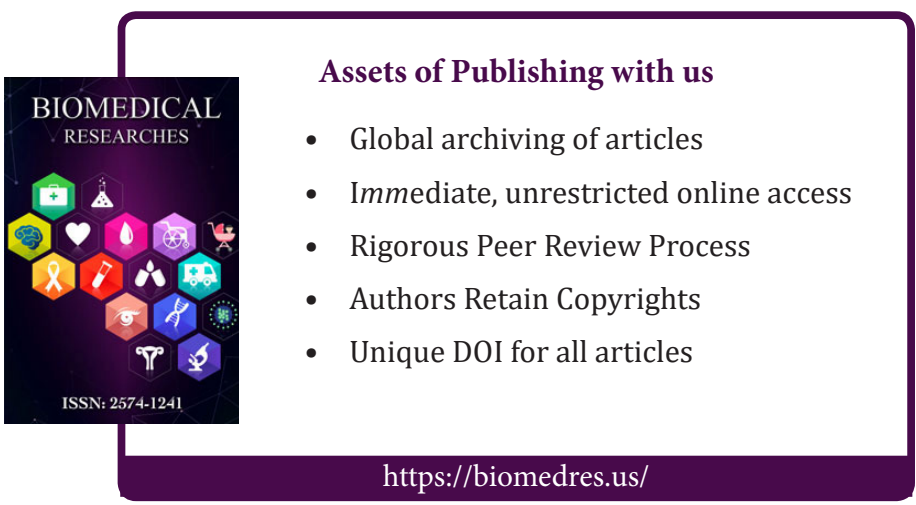

